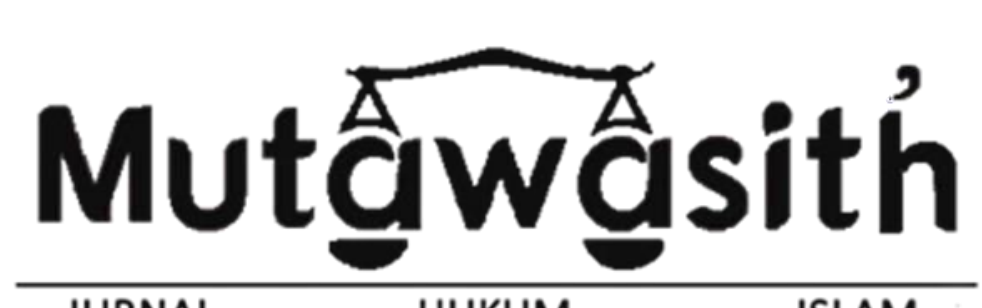

JURNAL HUKUM ISLAM

\title{
APLIKASI AKAD MURABAHAH PADA PORUDUK KONSUMTIF
}

\author{
Sartono, Lilis D. Hadaliah \\ Sekolah Tinggi Agama Islam Miftahul Huda Al-Azhar (STAIMA), Indonesia \\ Fakultas Syariah, IAILM Tasikmalaya, Indonesia \\ Email: sartonocakep4@gmail.com lilisdjumanahhadaliah@gmail.com
}

\begin{abstract}
Abstrak
Akad murabahah yang berbasisjual belidiharapkan menjadi solusisistem bagihasil yang cenderung high risk. Penentuan keuntungan di depan sebenarnya sah dan benar menurut syariah, karena murabahah merupakan akad berbasis jual beli yang berarti berorientasi sesuatu yang riil. Penelitian bertujuan: 1) Menganalisis kegiatan jasa keuangan yang dikembangkan oleh BMT Al-Amanah Ciawi Tasikmalaya 2) menganalisis produk konsumtifyang dapatdifasilitasioleh BMT Al-Amanah Ciawi Tasikmalaya, 3) menganalisis aplikasi akad Murabahah di BMT Al-Amanah Ciawi Tasikmalaya Penelitian ini menggunakan metode deskriptifkualitatifdenganjenispenelitianlapangan(fieldresearch) dengan logika induktif, yakni pengamatan penggambaran dan penguraian data secara sistematik. Untuk membantu pengumpulan data menggunakan metode observasi, wawancara, dan dokumentasi. Alat analisis data adalahdeskriptifkualitatif. Hasilnya dapat disimpulkan: 1) Kegiatan jasa keuangan yang ada di BMT Al-Amanah Ciawi Tasikmalaya yaitu: Jasa keuangan simpanan dan jasa keuangan pembiayaan. 2) pembiayaan produk konsumtifmenggunakan produk ba'l al-musawwamah yangmerupakan aplikasi dariakad murabahah, terdapat beberapa ketentuan mengenai produk yang diinginkan atau dibutuhkan. 3). BMT Al-Amanah Ciawi Tasikmalaya menerapkan konsep akad jual-beli (murabahah) kedalam 2 produk pembiayaan yaitu produk murabahah yang merupakan produk pembiayaan barangbarang usaha atau produktif dan kedalam produk ba'l almusawwamah untuk barang-barang konsumtif.
\end{abstract}

Katakunci:akad, murabahah, barangkonsumtif

\begin{abstract}
Sales-based Akad Murabahah is expected to be a system solution for the results that tend to be high risk. The profit-making in front is actually valid and true according to Sharia, because Murabahah is a sales-based contract which means something oriented real. Research aims: 1) analyzing the activities of financial services developed by BMT Al-Amanah Ciawi Tasikmalaya 2) analyzing consumptive products that can be facilitated by BMT AlAmanah Ciawi Tasikmalaya, 3) analyzing application AkadMurabahah in BMT Al-Amanah Ciawi Tasikmalaya This research uses qualitative descriptive methods with the type offield research with inductive logic, namely observation of depiction and systematic data parsing. To help with data collection using observation methods, interviews, and documentation. Dataanalysistools are qualitative descriptive. Theresultcanbeconcluded:1) The financial
\end{abstract}


services activities in BMT Al-Amanah Ciawi Tasikmalaya are: financial storage and financial services financing. 2) Consumptive product financing using the product of Ba'i alMusawwamah which is an application of Akad Murabahah, there are some provisions regarding the desired product or needed. 3). BMT Al-Amanah Ciawi Tasikmalaya implements the concept of trading contract (Murabahah) into 2 financing products namely Murabahah products which is a product of goods financing or productive products and into the product of Ba'i Al-musawwamah for goods Consumerist.

Keywords: Akad, murabahah, consumptive goods

\section{PENDAHULUAN}

Islam sebagai pedoman hidup manusia, tidak hanya mengatur ibadah ritual, tetapi merupakan aturan lengkap yang mencakup aturan ekonomi. Ekonomi tidak bisa lepas dari kehidupan manusia, sehingga tidaklah mungkin Allah SWT tidak mengatur hal yang demikian penting. Salah satu contoh dapat kita lihat dalamQ.S Al-Baqarah (2): 282, yang mengatur secara cukup terperinci aturan Muamalah diantara manusia yaitu:

Hai orang-orang yang beriman, apabila kamu bermu'amalah tidak secara tunaiuntukwaktu yang ditentukan, hendaklah kamumenuliskannya"(Q.S AlBaqarah (2): 282).

Banyak bermunculan lembaga ekonomi yang berusaha menerapkan prinsip syariat Islam, terutama lembaga-lembaga keuangan seperti perbankan, asuransi, dan BaitulMal wat Tamwil(BMT). Khusus mengenai BMT, menurut data yang ada, saat ini telah berdiri kurang lebih dua ribu BMT di seluruh Indonesia. ${ }^{1}$

Salah satu bentuk Muamalah lembaga keuangan syariah adalah jual beli. Jual beli adalah proses pemindahan hak milik (barang atau harta) kepada pihak lain dengan menggunakan uang sebagai alat tukarnya. Dasar hukum yang memperbolehkan jual beli ini dapat dilihat dalam AI-Quran, antara lain:

"Padahal Allah telah menghalalkan jual beli dan mengharamkan riba." (Q.S Al-Baqarah (2) : 275). "Hai orang-orang yang beriman, janganlah kamu saling

1 Widodo, Hertanto dkk, Panduan Praktis Operasional Baitul Mal wat Tamwil (BMT) (Jakarta

: Mizan, 1999), hlm. 43 
memakan harta sesamamu dengan jalan yang batil kecuali dengan jalan perniagaan yang berlaku suka sama suka diantara kamu. dan janganlah kamu membunuh dirimu, Sesungguhnya Allah adalah Maha Penyayang kepadamu" (Q.S An-Nisa (4) : 29).

Salah satu bentuk jual beli yang diperbolehkan dan lazim dan berkaitan dengan BMT adalah murabahah. Murabahahadalah jual beli suatu barang dengan pembayaran ditangguhkan. Maksudnya, pembeli baru membayar pada waktu jatuh tempo dengan harga jual sebesar harga pokok ditambah keuntungan yang disepakati. Pada dasarnya, hak atas barang telah berpindah dari penjual kepada pembeli pada waktu barang diserahkan walaupun pembayaran belum lunas, dan disaat itulah hak dan kewajiban utang piutang di antara keduannya. Namun demikian, tujuan dari murabahah adalah membantu pihak-pihak yang tidak mempunyai kemampuan untuk membeli secara tunai. ${ }^{2}$

Murabahah adalah salah satu bentukjual belidan kontrak dagang murni, yang pada awal sejarahnya merupakan akad jual beli barang dengan cara menginformasikan harga pokok dan mark - up yang disepakati oleh penjual dan pembeli. Berdasarkan ijtihad sebagian ulama Islam kontemporer, meskipun tidak didasarkan pada teks al Quran dan hadits, murabahah kemudian mengalami transformasi menjadi salah satu instrumen pembiayaan yang pada akhirnya menjadi akad yang paling banyak diimplementasikan oleh Lembaga Keuangan Syariah (LKS), terutama BMT yang bergerak di bidang micro intermediary financial. Bahkan murabahah menjadi akad yang paling mendominasi di LKS terutama di Indonesia, karena ratarata mencapai $70 \%$ dari total rasio dana yang didistribusikan sebagai pembiayaan.

Murabahah bertransformasi menjadi akad pembiayaan, karena sistem bagi hasil yang sejak awal dirancang menjadi core product LKS ternyata mengalami banyak hambatan dalam wilayah praksis, namun implementasi murabahah sebagai instrumen pembiayaan akhirnya banyak menuai kritik. Kritik ini muncul, karena fakta empirik di lapangan, LKS dianggap tidak menerapkan murabahah secara syariah, hal ini disebabkan karakteristiknya yang memberikan keuntungan yang pasti dan ditetapkan dimuka, hingga murabahah berubah menjadi sekadar

2 Ibid., hlm. 49 
pembiayaan berbasis mark up yang memiliki karakteristik memberikan keuntungan yang pastidan ditetapkan dimuka, yang tentu saja sangat mirip dengankeuntungan yang diberlakukan dalam sistem bunga, sistem yang sejak awal justru berniat dianulir oleh ekonomisyariah.

Akad murabahah yang berbasis jual beli diharapkan menjadi solusi sistem bagi hasil yang cenderung high risk. Penentuan keuntungan di depan sebenarnya sah dan benar menurut syariah, karena murabahah merupakan akad berbasis jual beli yang berarti berorientasi sesuatu yang riil. Permasalahan muncul lebih pada pencairan dana pembiayaan yang berujung pada pihak yang memiliki kewenangan melakukan pembelian barang obyek jual beli, hal ini yang melatarbelakangi munculnya istilah murabahah wal wakalah, istilah yang merujuk pada pelaksanaan murabahah dengan mewakilkan pengadaan barang obyek jual beli kepada nasabah pengaju pembiayaan, yang berarti tidaksesuai konsep awal murabahah.

BMT adalah kepanjangan dari Baitul Mal wat Tammwil atau Balai usaha Mandiri Terpadu, yaitu Lembaga Keuangan Mikro (LKM) yang beroperasi berdasarkan prinsip-prinsip syariah. BMT mengembangkan usaha-usaha produktif dan investasi dalam meningkatkan kualitas kegiatan ekonomi pengusaha kecil.

BMT mendorong kegiatan menabung dan menunjang biaya kegiatan ekonominya seperti menerima titipan, zakat,infak, sedekah, serta menyalurkannya sesuai dengan peraturan dan amanatnya. Dengan demikian keberadaan BMT dapat dipandang memiliki dua fungsi utama, yaitu sebagai media penyalur pendayagunaan harta ibadah seperti zakat, infak, sedekah dan wakaf, serta dapat pula berfungsi sebagai institusi yang bergerak dalam investasi bersifat produktif sebagaimana layaknya Bank.

Pada fungsi kedua ini dapat dipahami bahwa selain berfungsi sebagai lembaga keuangan, BMT juga berfungsi sebagai lembaga ekonomi. Sebagai lembaga keuangan BMT bertugas menghimpun dana dari masyarakat (anggota BMT) yang diberikan pinjaman oleh BMT. Sedangkan sebagai lembaga ekonomi, BMTberhak melakukan kegiatan ekonomi, seperti mengelola kegiatan perdagangan, industri, dan pertanian. ${ }^{3}$ Berdasarkan latar belakang tersebut, tertarik untuk melakukan penelitian dengan tema inti hukum aplikasi akad

${ }^{3}$ Soemitra, Andri, Bank dan Lembaga Keuangan Syariah (Jakarta : Prenadamedia Grup, 2009), hlm. 452 
murabahah pada produk konsumtif di Baitul Mal wat Tamwil (BMT) Al-Amanah Ciawi Tasikmalaya. Berdasarkan latar belakang yang telah diuraikan, maka rumusan masalahnya adalah: Bagaimanakah aplikasi akad murabahah pada produk konsumtif di BaitulMalwat Tamwil(BMT) Al-Amanah Ciawi Tasikmalaya.

\section{METODOLOGI PENELITIAN}

Metode penelitian adalah suatu cara untuk mengerjakan sesuatu secara sistematis, dan metodologi adalah ilmu pengetahuan tentang proses berfikir, analisa berfikir serta mengambil kesimpulan yang tepat dalam suatu penelitian. Metode penelitian yang digunakan adalah metode kualitatif. Metode kualitatif ditujukan untuk memahami fenomena-fenomena sosial dari sudut atau perspektif partisipan. Partisipan merupakan orang-orang yang diajak wawancara, diobservasi, diminta memberikan data, pendapat, pemikiran, presepsinya.

Pengguna metode kualitatif ini disesuaikan dengan tujuan penelitian yaitu menganalisis aplikasi akad Murabahah pada produk konsumtif di Baitul Mal wat Tamwil (BMT) Al-Amanah Ciawi Tasikmalaya. Hipotesa 1: Aplikasi akad Murabahah pada produk konsumtif di BMT Al-Amanah Ciawi Tasikmalaya. Hipotesa 2 : Respon masyarakat terhadap Aplikasi akad Murabahah pada produk konsumtif di BMT AIAmanah Ciawi Tasikmalaya. positif.

Jenis Data

Sebagai jawaban atas pertanyaan penelitian yang diajukan terhadap masalah yang dirumuskan dan pada tujuan yang telah ditetapkan, maka jenis data yang dikumpulkan dalam penulisan ini adalah kualitatif, data yang digambarkan dengan kata-kata dan kalimat. Jenis data tersebut kemudian diklasifikasikan sesuai dengan butir-butir pertanyaan yang diajukan, serta menghindarkan dari jenis data yang tidak relevan dengan pertanyaan tersebut, walaupun dimungkinkan penambahan sebagai pelengkap.

Teknik Pengumpulan Data

Dalam pengumpulan data, penelitian ini menggunakan tiga cara, yaitu: Observasi 
Observasi yaitu melakukan pengamatan secara langsung di lokasi penelitian. Karena teknik pengamatan memungkinkan melihat dan mengamati sendiri, kemudian mencatat kejadian sebagaimana yang terjadi pada keadaan yang sebenarnya yaitu dengan melihat sekaligus mencermati bagaimana akadakad pembiayaan khususnya akad Murabahah di BMT Al-Amanah Ciawi Tasikmalaya.

\section{Metode Wawancara (Interview)}

Yakni suatu komunikasi yang bertujuan memperoleh informasi secara informatif. Wawancara diarahkan terhadap hal-hal yang menjadi permasalahan dan hal-hal yang kurangjelas.

\section{Dokumentasi}

Metode ini digunakan untuk mengumpulkan data dengan mencatat, menyalin dan menggandakan data atau dokumen yang berkaitan dengan aplikasi Murabahah di BMT Al-Amanah Ciawi Tasikmalaya.

\section{Analisa Data}

Setelah data dikumpulkan, kemudian kemudian diolah dan dianalisa dengan analisakualitatifdengan logikainduktif. Polaberpikir induktif iniuntuk menganalisis data-data yang bersifat khusus untuk ditarik kepada yang umum. Kemudian dari hasil analisa data yang diperoleh, dideskripsikan secara induktif deduktif.

\section{PEMBAHASAN DAN HASIL PENELITIAN}

Kegiatan JasaKeuangan di BMT Al-Amanah Ciawi Tasikmalaya Jasa Keuangan Simpanan

Dalam perkembangannya, lembaga keuangan syariah BMT Al-Amanah Ciawi Tasikmalaya mengembangkan jasa keuangan berupa jasa simpanan dan jasa pembiayaan bagi anggotanya. Jasa simpanan dan jasa pembiayaan yang disediakan dilayanan BMT AI-Amanah Ciawi Tasikmalaya adalah sebagai berikut:

\begin{tabular}{ll}
\hline \multicolumn{1}{c}{ Simpanan } & \multicolumn{1}{c}{ Keterangan } \\
\hline SIMANIS & $\begin{array}{l}\text { Adalah simpanan sukarela dimana anggota } \\
\text { dapat melakukan transaksi penarikan dan } \\
\text { penyimpanan kapan saja tidak dibatasi waktu. }\end{array}$
\end{tabular}

40 


\begin{tabular}{|c|c|}
\hline SIBERKAH & Adalah simpanan berjangka waktu 3,6,9 dan \\
\hline Simpanan Berjangka Barokah & $\begin{array}{l}12 \text { bulan, dengan tingak bagi hasil disesuaikan } \\
\text { dengan lamanya dan mengendap atau } \\
\text { digulirkan. }\end{array}$ \\
\hline SIMPANAN IDUL FITRI & $\begin{array}{l}\text { Adalah simpananyang dipersiapkanuntuk } \\
\text { kebutuhan menghadapi Idul Fitri, awal } \\
\text { tabungan dimulaibulan syawal dan diambil } \\
\text { bulan ramdhan. }\end{array}$ \\
\hline SIMPANAN POKOK & $\begin{array}{l}\text { Adalah simpanan anggota yang ingin } \\
\text { mendapatkan fasilitas pembiayaan, dengan } \\
\text { ketentuan tidakdiambilselamamenjadi } \\
\text { anggota. Selain itu, anggota yang memiliki } \\
\text { simpananpokokberhakmengikutirapat } \\
\text { anggota tahunan. Simpanan bisa diambil } \\
\text { apabila keluar darikeanggotaan atau } \\
\text { meninggal dunia. }\end{array}$ \\
\hline SIMPANAN WAJIB & $\begin{array}{l}\text { Adalah simapan khusus untuk masyarakat } \\
\text { yang sudah menjadi anggota dengan } \\
\text { mendapatkan pelayanan pembiayaan dan } \\
\text { berhakmengikuti rapatanggotatahunan. }\end{array}$ \\
\hline SIMPANAN POKOK KHUSUS & $\begin{array}{l}\text { Adalah simpanan yang harus disetor Rp. } \\
50.000,- \text { apabila ingin mendapatkan } \\
\text { pelayanan dari BMT, dengan status ANGGOTA } \\
\text { KHUSUS dan hanya bisa mengadakan } \\
\text { transaksi simpanan dan pengambilan saja. }\end{array}$ \\
\hline
\end{tabular}

Berdasarkan tabel di atas, dapat dilihat bahwa BMT Al-Amanah Ciawi Tasikmalaya menyediakan berbagai fasilitas simpanan yang terdiri dari beberapa produk. Hal ini disediakan oleh BMT Al-Amanah Ciawi Tasikmalaya guna memberikan fasilitaskepada anggota dalam kegiatan menabung atau menyimpan danaanggota. Fasilitas simpanan ini bukan hanya sebagai suatu produk diBMTAIAmanah Ciawi Tasikmalaya, namun fasilitas ini bertujuan untuk memfasilitasi tujuan 
BMT Al-Amanah Ciawi Tasikmalaya dalam upaya mewujudkan kesejahteraan anggotanya.

Jasa Keuangan Pembiayaan

Selain jasa keuangan simpanan, BMT Al-Amanah Ciawi Tasikmalayajuga menyediakan fasilitas keuangan lainnya yang merupakan salah satu hal yang sangat penting dalam mewujudkan kesejahteraan anggota yakni jasa keuangan pembiayaan. Seperti halnya jasa keuangan simpanan, jasa keuangan pembiayaan juga terbagi ke dalam beberapa produk. Produkproduk ini diharapkan dapat memenuhi kebutuhan dan keinginan anggota guna meningkatkan taraf hidup anggotanya, karena dengan adanya jasa keuangan pembiayaan ini dapat membantu anggota yang mengalami kesulitan baik dalam kegiatan usaha (produktif) maupun dalam keinginan untuk memiliki suatu barang (konsumtif).

Adapun produk-produk jasa keuangan pembiayaan tersebut dapat dilihat pada tabel berikut :

\begin{tabular}{ll}
\hline \multicolumn{1}{c}{ PEMBIAYAAN } & \multicolumn{1}{c}{ KETERANGAN } \\
\hline MURABAHAH & $\begin{array}{l}\text { Adalah pembiyaan pemenuhan kebutuhan barang- } \\
\text { barang modal produksi, barang dagangan, stok } \\
\text { barang, pesanan barang. }\end{array}$ \\
\hline AL-QARD & $\begin{array}{l}\text { Adalah pembiayaan kebijakanuntuk memberikan } \\
\text { kemudahan kepada anggota apabila hendak } \\
\text { mengadakan hajatan, berobatke rumah sakit, atau } \\
\text { keperluan lain yang mendesak, dengan tidak } \\
\text { menentukan keuntungan yang diharapkan. }\end{array}$ \\
\hline BA'I MUSAWWAMAH & $\begin{array}{l}\text { Adalah akad jual-beli barang pesanan dengan } \\
\text { pembayaran dicicil dengan jangka waktu yang } \\
\text { disepakati. }\end{array}$ \\
\hline IJARAH & $\begin{array}{l}\text { Adalah pembiayaan yang diberikan kepada anggota } \\
\text { untuk talangan umrah atau haji, biaya pendidikan, } \\
\text { pembayaran ruamah sakit. }\end{array}$ \\
\hline
\end{tabular}


Jasa keuangan pembiayaan ini sangat bermanfaat bagi anggota yang mengalaimi kesulitan dalam hal bantuan modal usaha ataupun bantuan untuk memenuhi keinginan kepemilikan barang yang diinginkan anggota.

Berdasarkan hasil penelitian yang telah dilakukan penulis, jasa keuangan di BMT Al-Amanah Ciawi Tasikmalaya selalu berpegang pada prinsip-prinsip syariah baiksecarateorimaupun dalam praktiknya. Hal ini dapat disimpulkan berdasarkan hasil wawancara dengan ibu Wina Nuraeni yang menjabat sebagai customer service di BMT AIAmanah Ciawi Tasikmalaya memberikan penjelasan bahwateori dan praktik keuangan syariah selalu diterapkan dalam setiap kegiatan keuangan di BMT Al-Amanah CiawiTasikmalaya. Keterangan tersebut dikuatkan oleh pernyataan beberapa anggota yang ditemui dan diwawancara oleh penulis pada saat penelitian.

Praktik keuangan di BMT AIAmanah Ciawi Tasikmalaya yang selalu menerapkan ketentuan syariah baik secara teori maupun dalam praktiknya menjadi salah satu kelebihan yang dimiliki BMT AIAmanah CiawiTasikmalayadari lembaga keuangan lainnya baik lembaga keuangan non-bank bahkan lembaga keuangan perbankan.

Produk/Barang Konsumtif yang dapat Dibiayai oleh BMT Al-Amanah Ciawi Tasikmalaya

Berdasarkan hasil penelitian yang telah dilakukan penulis, semua jenis produk/barang yang diinginkan oleh anggota dapat difasilitasi pembiayannya oleh BMT Al-Amanah Ciawi Tasikmalaya. Namun, hal ini tidak berarti semua produk/barang dapat dimilikiatau dapat diproses pembiayaannya karenatentunya ada kriteria produk, persyaratan dan ketentuan yang harus dipenuhi baik oleh anggota maupun dari segi produk/barang itu sendiri. Kriteria produk/barang tersebutdapatdilihat padasyarat dan ketentuan yang adapadabrosurpembiayaan konsumtif BMT AIAmanah Ciawi Tasikmalaya seperti harga maksimal harga barang untuk pembiayaan konsumtif yaitu paket SERBU tidak melebihi Rp.600.000,--atau produkmurabahah yang diajukan dapatlebih dari 1 jenis barang dengan batas total harga maksimal 5 juta rupiah dengan jangka waktu cicilan maksimal selama 12 bulan.

Dalam prosedur pembayaran cicilan produk konsumtif ini terdapat beberapa pilihan yakni pembayaran secara harian, mingguan dan bulanan. Pola 
pembayaran cicilan ini dipilih berdasarkan kesepakatan bersama antara anggota dan petugas marketing yang bersangkutan. Berdasarkan hasil wawancara penulis dengan beberapa anggota yang ditemui di BMT Al-Amanah Ciawi Tasikmalaya, mayoritas anggota yang memakai produk pembiayaan konsumtif memilih untuk melakukan pembayaran dengan pola pembayaran bulanan. Hal ini diambil berdasarkan musyawarah yang mempertimbangkan kemudahan untuk kedua belah pihak yakni pertimbangan kesulitan yang dihadapi petugas yang memberikan pelayanan pengambilan cicilan ke rumah anggota yang lokasinya jauh dari kantor BMT AI-Amanah Ciawi Tasikmalaya jika dilakukan pengambilan cicilan oleh petugas setiap hari.

\section{Aplikasi Akad Murabahah di BMT Al-Amanah Ciawi Tasikmalaya}

Aplikasi akad murabahah merupakan sistem balas jasa/pembiayaan yang paling diminati dibandingkan dengan produk lainnya. Akad murabahah merupakan jual beli barang yang menyatakan harga perolehan dan keuntungan yang disepakati antara penjual dan pembeli, sehingga keduanya terikat oleh perjanjian dan hukum yang telah dibuat bersama. Kebutuhan akan modal membuat pembiayaan ini banyak yang dipilih anggota.

Praktik Murabahah di BMT AIAmanah Ciawi Tasikmalaya

Salah satu kegiatan operasional BMT Al-Amanah Tasikmalaya yang menggunakan prinsip sistem balasjasa adalah Murabahah. Sistem ini merupakan suatu tata cara jual beli yang dalam pelaksanaannya BMT mengangkat masalah sebagai agen yang diberi perhitungan kemampuan kuasa melakukan pembelian barang angsuran calon atas nama BMT, kemudian nasabah/anggota dengan bertindak sebagai penjual, dengan batasan waktu diatur menjual barang yang sudah dalam SK Pengurus ditambah dengan nilai mark-up. 8. Sistem angsuran Dalam proses akad Murabahah disesuaikan dengan jenis terdapat ketentuan umum dalam volume usaha calon proses pembiayaannya, diantaranya debitur, dengan alternatif angsuran mingguan: 
1. Permohonan harus bulanan dan angsuran dilengkapi KTP, KK, SIUP sekaligus untuk badan usaha dan 9 . Perpanjangan waktu surat keterangan lainnya; pembiayaan harus

2 Pembiayaan digunakan didasarkan penilaian untuk pengembagan usaha kembali terhadap debitur anggota Berdasarkanhasil wawancara.

3. Pembiayaan dijamin dengan Wina Nuraeni sebagai dengan jaminan yang customer service di BMT Almencukupi, baik berupa Amanah Ciawi Tasikmalaya, tahapbarang bergerak, maupun tahap pemberian tidak bergerak kredit/pembiayaan adalah sebagai 4 . Jika jaminan atas nama berikut :

4. orang lain, harus ada surat 1. Tahap persiapan, yaitu kuasa bermaterai dari Tahap ini merupakan pemilik kepada calon tahap permulaan dengan debitur, pemilik maksud untuk saling menanggung risiko apabila mengetahui informasi pembiayaan mengalami calon debitur dengan kemacetan lembaga keuangan.

5. Atas pembiayaan yang 2. Tahap analisis atau diberikan dikenakan biaya penilaian pembiayaan, administrasi dan asuransi yaitu penilaian yang dengan pembiayaan diatur mendalam tentang keadaan dengan SK pengurus usaha atauproyek

6. Pembiayaan diberikan pemohon pembiayaan. berdasarkan hasil penilaian 3. Tahap keputusan atas usaha calon debitur, kredit/pembiayaan, yaitu prospek usahanya, karakter memutuskan bahwa dan kapasitas pemilik, pengajuan pembiayaan jaminan, aspek hukum, yang diajukan oleh calon serta kondisi debitur diterima atau perekonomian yang dapat ditolak berdasarkan dari mempengaruhi usaha calon hasil analisis.

7. Jangka waktu pembayaran administrasi pembiayaan, ditetapkan berdasarkan yaitu melengkapi persyaratan-persyaratan yang telah ditentukan pihak lembaga keuangan dan menyusun perjanjian berupa akad.

8. Supervisi, yaitu tahap pengawasan dan pembinaan dari pihak lembaga keuangan terhadap debitur setelah debitur dikabulkan permohonan pembiayaannya. 
Prosedur yang dimiliki Al-Amanah Ciawi Tasikmalaya dalam menangani pembiayaan adalah prosedur permohonan kredit (pembiayaan), yang fungsinya sama dengan tahap persiapan, prosedur pemeriksaan, yang fungsi dan kegiatannya sama dengan tahap analisis, prosedur persiapan realisasi pembiayaan yang terdiri dari persetujuan pembiayaan, pemeriksaan berkas, prosedur administrasi kredit dan prosedur pelayanan angsuran kredit.

Secara keseluruhan praktek akad Murabahah di Al-Amanah Ciawi Tasikmalaya dapat dikatakan sudah baik, karena dalam pelaksanaannya setiap orang yang ingin menjadi nasabah pembiayaan di BMT Al-Amanah Ciawi Tasikmalaya harus memenuhi syarat dan prosedur yang berlaku sehingga dari ketentuan tersebut mencegah anggota yang nantinya bermasalah.

Respon Anggota Terhadap Aplikasi Murabahah di BMT Al-Amanah Ciawi Tasikmalaya

Dalam memilih pembiayaan, ada beberapa faktor yang mempengaruhi anggota memilih pembiayaan tersebut, baik faktor internal pribadi anggotaitu sendiri maupun faktor eksternal yang mempengaruhinya. Hal ini terjadi pada saat proses pembelian. Menurut Kotler, seseorang mengambil keputusan pembelian melalui lima tahapan, yaitu pengenalan terhadap kebutuhan, pencarian informasi, evaluasi alternatif, keputusan pembelian dan purna atau pasca pembelian.

Berdasarkan hasil wawancara dengan anggota yang melakukan transaksi pembiayaan, anggota merespon akad murabahah dengan positif. Hal ini dikarenakan akad murabahahmenyatakan harga perolehan dan keuntungan yang disepakati antara penjual dan pembeli, sehingga keduanya terikat oleh perjanjian dan hukum yang telah dibuat bersama. Pada akhirnya, hal ini membantu nasabah untuk memutuskan mengambil suatu pembiayaan dengan perjanjian yang telah disepakati dari awal. Karakteristik akad murabahah yang profitable, mudah dalam penerapan dan memiliki resiko yang ringan untuk diperhitungkan. Namun penentuan besarnya tingkat keuntungan menjadi salah satu hal yang menjadi perhatian nasabah.

BMT Al-Amanah Ciawi Tasikmalaya dalam menetapkan keuntungannnya tidak semata-mata ditetapkan sendiri secara sepihak, melainkan mengacu pada standar penetapan margin murabahah yang ditetapkan BMT AI-Amanah pusat. Dengan 
demikian, respon anggota terhadap aplikasi murabahah di BMT AI-Amanah sangatlah baik danpositif.

Produk BMT Al-Amanah Ciawi Tasikmalaya yang mengaplikasikan akad jual-beli (Murabahah)

BMT Al-Amanah CiawiTasikmalaya mengaplikasikan akad jual-beli (murabahah) ke dalam 2 produk pembiayaan yakni produk murabahah dan produk ba'i al musawwamah. Seperti yang telah dijelaskan sebelumnya, produk murabahah yaitu produk pembiayaan yang dengan akad jual beli untuk pembiayaan produktif sedangkan produk ba'i al musawwamah adalah produk pembiayaan untuk barang-barang konsumtif. Kedua produk ini menggunakan pola pembayaran yang sama yakni pembayaran secara cicilan. Kedua produk aplikasi akad murabahah ini tentu terdapat perbedaan diantara keduanya selain mengenai barang yang dibiayainya yaitu salah satu perbedaannya terdapat pada perbedaan margin yang diterapkan.

Margin yang diterapkan pada kedua produkini memiliki perbedaan sekitar 1$1,5 \%$ dengan margin produk pembiayaan murabahah lebih besar daripada margin produk ba'i al musawwamah. Hal ini mengacu pada penggunaan dana pembiayaan yang diberikan oleh BMT Al-Amanah Ciawi Tasikmalaya yaitu pada produk pembiayaan murabahah digunakan untuk kegiatan produktif yang tentunya mengusahakan mendapatkan keuntungan sedangkan produk ba'i al musawwamah hanya sebatas memenuhi keinginan atau kebutuhan anggota.

Risiko Pembiayaan Akad Murabahah

Risiko tentunya selalu ada dalam setiap hal, apalagi menyangkut kegiatan pembiayaan. Hal ini berlaku juga dalam pembiayaan akad murabahah yang dilakukan BMT Al-Amanah Ciawi Tasikmalaya. Risiko yang timbul atau diperkirakan akan timbul dapat dikelola melalui beberapa hal seperti yang dilakukan oleh BMT Al-Amanah Ciawi Tasikmalaya. BMT Al-Amanah Ciawi Tasikmalaya mengelola risiko yang mungkin timbul dalam pembiayaan dilakukan melalui beberapa tahap yaitu mulai darianalisa proposal pengajuan kredit, data personal anggota maupun datadata lain yang dapat meminimalisir risiko masa depan. Pengelolaan risiko selanjutnya dilakukan melalui evaluasi proses pembayaran kredit ataupun pasca 
pelunasan kredittersebut. Hal ini dilakukan untukmengkaji pembiayaan yang akan dilakukan selanjutnya.

Salah satu risiko dalam pembiayaan ini salah satunya adalah kredit macet. Hal ini seringkali terjadi dalam akad pembiayaan, seperti dalam halnya akad pembiayaan konsumtif. Berdasarkan wawancara penulis dengan pihak BMT AIAmanah Ciawi Tasikmalaya, terdapat beberapa kejadian kredit macet yang pernah terjadi pada produkpembiayaan.

Dalam produk pembiayaan konsumtif yang dalam hal ini produk pembiayaan ba'ialmusawwamah pernah terjadikreditmacet. Pengelolaan kredityang macetini dilakukan melalui beberapa tingkatan tindakan seperti melakukan panggilan via telepon atau sms, melakukan kunjungan musyawarah langsung ke rumah anggota, hal ini dilakukan oleh BMT Al-Amanah Ciawi Tasikmalaya supaya ada solusi yang jelas atas permasalahan kredit ini.

Adapun pertimbangan pihak BMT Al-Amanah Ciawi Tasikmalaya dalam melakukan tindakan kredit macet akad ba'i al-musawwamah ini salah satunya dengan mempertimbangkan kategori dari anggota yang memiliki kredit macet. Kategori tersebut adalah :

a. Anggota yang melakukan usaha penyelesaian permasalahan juga memiliki niat yang baik;

b. Anggota yang memiliki niat tetapi tidak melakukan usaha;

c. Anggota yang tidak memiliki niat dan usaha;

Hal ini sesuai dengan ketentuan Al-Quran sebagai berikut:

"Dan jika (orang yang berhutang itu) dalam kesukaran, maka berilah tangguh sampai dia berkelapangan. Dan menyedekahkan (sebagian atau semua utang) itu, lebih baik bagimu, jika kamu mengetahui"(Q.S Al-Baqarah (2) :280).

Kelebihan Produk Ba'i Al-musawwamah

Produk ba'i al-musawwamah memiliki konsep dan teori yang sama dengan lembaga keuangan syariah lainnya yang menyediakan produk sejenis yakni produk pembiayaan konsumtif. Produk ba'i al-musawwamahyang merupakan salah satu produk aplikasi digunakan untuk akad murabahah dalam produk pembiayaan konsumtif di BMT AIAmanah Ciawi Tasikmalaya memiliki beberapa kelebihan yaitu: 
a. Teori dan praktik produk ba'i al-musawwamah di BMT Al-Amanah Ciawi Tasikmalaya menggunakan azas syariah.

Secara teori tentu produk pembiayaan ba'i almusawwamah menggunakan teori-teori syariah yang kemudian tersusun ke dalam persyaratan dan ketentuan dalam produk ini. BMT Al-Amanah Ciawi Tasikmalaya juga melakukan praktik yang sesuai syariah dimana anggota tidak menerima uang pembiayaan melainkan menerima produk yang diinginkan atau dibutuhkan anggota.

Adapun jika pihak BMT Al-Amanah Ciawi Tasikmalaya tidak mendapatkan barang yang dibutuhkan atau diinginkan anggota dan anggota mengetahui lokasi untuk mendapatkan barang tersebut, maka pihak BMT Al-Amanah Ciawi Tasikmalaya menemani anggota dalam proses pembeliannya. Hal ini dilakukan sebagai bentuk pengawasan atau antisipasi penyelewengan dana pembiayaan. Sehingga danapembiayaan yang disalurkan tepat sasaran sesuai akad yang dilakukan sebelumnya.

b. Sebagai bentuk pelayanan ekstra yang diberikan BMT

Al-Amanah Ciawi Tasikmalaya, dalam pembayaran cicilan kredit yang dilakukan anggota, anggota dapat menitipkan uang pembayaran cicilan kepada petugas yang bersangkutan atau petugas yang bersangkutan tersebut dapat mendatangi langsung ke lokasi usaha atau rumah anggota untuk memberikan kemudahan pembayaran cicilan.

c. Selalu melakukan musyawarah dengan anggotabaik sebelum akad atau jika terdapat permasalahan.

Dalam praktiknya, BMT Al-Amanah Ciawi Tasikmalaya melakukan musyawarah dengan anggota mengenai persentase margin yang ditetapkan maupun mengenai pola pembayaran yang akan dilakukan. Hal ini menjadi nilai lebih bagi BMT Al-Amanah Ciawi Tasikmalaya yang dapat menjadi pembeda dengan lembaga keuangan syariah lainnya yang terkadang margin pembiayaan telah ditetapkan oleh satu pihak dan tidak dapat dimusyawarahkan.

Jika terdapat permasalahan pun, BMT Al-Amanah Ciawi Tasikmalaya selalu berusaha menggunakan musyawarah sebagai cara mencari jalan keluar dan berusaha tidak memutuskan keputusan secara sepihakjika terdapat peluang atau usaha positif dari anggota yang mengalami masalah. Namun, jika anggota tidak ada itikad baik untuk menyelesaikan permasalahan tersebut, maka terpaksa pihak BMT 
Al-Amanah Ciawi Tasikmalaya melakukan tindakan sepihak sesuai akad yang telah disepakati sebelumnya.

\section{SIMPULAN}

Berdasarkan hasil penelitian baik melalui observasi, studi pustaka, wawancara maupun melalui analisa dokumentasi, dapat menyimpulkan: Kegiatan jasa keuangan yang ada di BMT Al-Amanah Ciawi Tasikmalaya yaitu: Jasa keuangan simpanan. Dalam jasa keuangan simpanan ini terdapat beberapa produk yaitu:

- Simanis (simpanan

- Andalan umat islam)

- Siberkah (simpanan

- Berjangkabarokah)

- Simpanan idulfitri

- Simpanan pokok

- Simpanan wajib

- Simpanan pokok Khusus

a. Jasa keuangan pembiayaan

Dalam jasa keuangan simpanan ini terdapat beberapa produk yaitu :

- Murabahah

- Al-qard

- Ba'i al-Musawwamah

- ljarah

Produk konsumtif yang dapat dibiayai oleh BMT Al-Amanah Ciawi Tasikmalaya dalam pembiayaan produk konsumtif yang dalam hal ini menggunakan produk ba'i al-musawwamah yang merupakan aplikasi dari akad murabahah, terdapat beberapa ketentuan mengenai produk yang diinginkan atau dibutuhkan. Karena secara umum ,semua barang yang diinginkan atau dibutuhkan oleh anggota dapat difasilitasi pembiayaannya oleh BMT Al-Amanah Ciawi Tasikmalaya. Ketentuan tersebutberupakriteria produk/barang yang diinginkan atau dibutuhkan oleh anggota, harga dan pola pembayaran cicilan barang tersebut.

Aplikasi akad murabahah di BMT Al-Amanah Ciawi Tasikmalaya BMT AlAmanah Ciawi Tasikmalaya menerapkan konsep akad jual-beli (murabahah) ke dalam 2 produk pembiayaan yaitu produk murabahah yang merupakan produk 
pembiayaan barang-barang usaha atau produktif dan ke dalam produk ba'i almusawwamah yang merupakan produk pembiayaan untuk barang-barang konsumtif. Produk tersebut memiliki beberapa perbedaan baik dari segi barang yang diperjualbelikannya maupun dari segi prosedur yang dilakukan dalam proses akad maupun pembayarannya. Produk yang menjadi bahan penelitian penulis dalam penelitian ini adalah produk ba'i almusawwamah yang mengaplikasikan akad murabahah dalam pembiayaan konsumtif. Produk pembiayaan ini menggunakan konsep akad jual-beli dalam pembiayaan konsumtif yang disediakan oleh BMT AlAmanah Ciawi Tasikmalaya dalam rangka membantu anggota memenuhi keinginan dan kebutuhan anggotanya sehingga tujuan utama BMT Al-Amanah Ciawi Tasikmalaya yaitu mensejahterakan anggotanya.

\section{DAFTAR PUSTAKA}

Andri, Soemitra. 2009. Bank dan Lembaga Keuangan Syariah. Jakarta

Prenadamedia Grup.

Antonio, Muhammad Syafi'l. 2001. BANK SYARIAH Dari Teori ke Praktik. Jakarta: Gema Insani.

Azis M. Amin, 2008. Tata Cara Pendirian BMT. Jakarta: PKES Publishing. Budiharjo, Arief. 2003. Pengenalan BMT. Bandung. MESS Jabar. Abdul, Aziz Dahlan. 1996. Ensiklopedia Hkum Islam. Jilid 2 Jakarta : Intermasa, Ainur Rahim Faqih Departemen Agama. 2010. Al-Quran Terjemah dan Tajwid., Bandung : CV. Penerbit Diponogoro.

Maniati, Neni Sri. 2010. Aspek-aspek Hukum BMT (Baitul Maal wat Tamwil). Bandung : PT Citra Aditya Bakti.

Lubis, Suhrawardi K. 2000. Hukum Ekonomi Islam. Jakarta : Sinar Grafika. Mahkamah Agung Republik Indonesia. 2008. KOMPILASI HUKUM EKONOMI SYARI'AH. Jakarta: Direktorat Jendral Badan Peradilan Agama.

Kotler, Philip dan Gary Amstrong, 2001. Prinsip-Prinsip Pemasaran. Jakarta: Erlangga

Ridwan Muhammad. 2008. Sistem dan ProsedurPendirian Baitul Mal watTamwil(BMT).Yogyakarta: Citra Media.

Sabik Sayyid, 2006. Fiqih Sunnah. Jakarta Selatan: Pena Pundi Aksara. Soemitra, Andri. 2009. Bank dan Lembaga Keuangan Syariah. Jakarta : Prenadamedia Grup. 
Aplikasi Akad Murabahah Pada

Poruduk Konsumtif

Sudarsono, Heri. 2004. Bank dan Lembaga Keuangan Syariah, Yogyakarta: Ekonisia, Tohar, M. 2000. Membuka Usaha Kecil. Yogyakarta : Kanisius.

Widodo, Hertanto dkk. 1999. Panduan Praktis Operasional Baitul Mal wat Tamwil (BMT). Jakarta :Mizan.

Wiroso. 2005. Jual Beli Murabahah. Yogyakarta : UII Pres.

Rasyid, Sifudin A. 2005. Pusat Inkubasi Bisnis Usaha Kecil, Konsep DasarBMT.

: Republika Online.

Hafizh, Muhammad. Pengertian Murabahah dan

Konsepnya menurut

Para Ahli. [online] Tersedia :

http://www.muhammadhaf izh.com/pengertianmurabahah. 